\title{
Levín, Florencia (2013). Humor político en tiempos de represión, Clarín 1976-1983, Buenos Aires: Siglo XXI, 320 páginas \\ por Valeria Segovia
}

Universidad Nacional de General Sarmiento

vsegovia85@gmail.com

En los últimos tiempos en Argentina se han publicado diversos trabajos de investigación sobre la última dictadura militar que ponen el acento en intentar comprender cómo fue la sociedad donde el terrorismo de Estado tuvo lugar. Es aquí donde podemos ubicar el libro de Florencia Levín Humor politico en tiempos de represión, Clarin 1973-1983, reelaboración de su tesis de doctorado, cuyo objetivo central de este trabajo es mostrar el rol y funcionamiento de la prensa. En el mencionado libro se pretende explorar el entramado simbólico construido en el espacio de humor del diario Clarín y además se propone reflexionar sobre cómo fue posible que circulara el horror a través del espacio de humor del periódico.

Florencia Levín se preocupa por el rol de la prensa en dictadura, y analiza una sección de diarios que no había sido tomada en cuenta por los Historiadores hasta el momento, como es la humorística. El recorrido del libro se basa en el análisis de diversas viñetas y cartoons publicadas tanto en la contratapa del diario como dentro del cuerpo principal acompañando a las diferentes noticias que formaban parte del diario. Las fuentes que conforman su investigación son más de 15000 misceláneas que fueron digitalizadas, analizadas y categorizadas por la autora. El período de análisis que propone Levín es desde el retorno del peronismo en 1973 hasta la conclusión del régimen militar en diciembre de 1983. Si bien el libro se centra exclusivamente en el régimen militar, la autora hace un recorte temporal anterior.

El libro se compone de seis capítulos donde se realiza un recorrido desde distintos recortes y preocupaciones de la Historia argentina reciente siguiendo un orden cronológico con una alteración en los capítulos 3 y 4 donde se da un corte temático.

En el primero de ellos se presenta el proceso de nacionalización de los espacios de humor del diario Clarín en el contexto de la transición que llevó al peronismo por tercera vez al gobierno. El capítulo titulado «Humor y politización» realiza una presentación del diario y de cada uno de los humoristas que publicaron en sus páginas, haciendo hincapié en los detalles biográfi

rrer este primer capítulo también nos encontramos con el análisis de las implicancias del proceso de nacionalización del humor gráfico a través de las viñetas, así como también de la agitada realidad social a través de las imágenes. A través de la nacionalización de la sección se da una revalorización de la importancia del humor. Clarín comienza a construir una comunidad simbólica que logrará facilitar los vínculos entre lectores y humoristas. Finalizando este primer capítulo la autora plantea que a partir del proceso de nacionalización del humor gráfico, los nuevos escenarios, 
conflictos y personajes habilitaron nuevos juegos, vínculos y complicidades entre los humoristas y los lectores de Clarin.

En el segundo capítulo titulado "Último acto» se analiza la participación del humor gráfico y del diario Clarín en el clima golpista que llevó al 24 de Marzo. Este clima estuvo auspiciado por dos aspectos fundamentales, la débil presidencia de María Estela Martínez de Perón y el apoyo de un discurso avalador de la intervención militar. Aquí Florencia Levín realiza un análisis minucioso de las estrategias humorísticas en el marco de la gran aceleración de las prácticas y los discursos de la censura y la represión. Por un lado, las caricaturas de Landrú mostraban cómo de manera vertiginosa se descomponía el gobierno peronista. Este humorista de manera ingenioso hacía referencia a la fi pero de manera indirecta dado que estaba prohibido, la manera de hacerlo era hablando de otra cosa, caricaturizando a otros personajes sin retratarla y sin ni siquiera nombrarla. Por otro lado, y en lo que refi

en la contratapa, Crist y Fontanorrosa se mostraron atemorizados por lo que vendría después, pensando que sería mucho peor que lo que estaba aconteciendo según señala Levín.

En el tercer capítulo llamado «El humor reprimido» la autora realiza un recorrido más largo a diferencia de los demás capítulos el cual abarca desde el golpe de Estado hasta el estallido de la guerra de Malvinas. Aquí se analizan las secciones de humor del diario en relación con la dimensión político-institucional del régimen. $\mathrm{Al}$ mismo tiempo la autora explora las complejas estrategias del humor para sobrevivir a la censura y el análisis de las relaciones de los humoristas con el poder militar.
En el capítulo siguiente «Sobre el miedo y el terror» se analizan en profundidad las representaciones sobre la dimensión terrorista y clandestina del poder desaparecedor y vuelve tomar el período previo a 1976. Aquí se propone una mirada de largo plazo que une el accionar de la Triple A con el desarrollo del conflicto de Malvinas. Se estudia la participación de los humoristas y de Clarín en el combate simbólico por la semantización de las prácticas que convergieron poco antes del Golpe de Estado en el consenso sobre la necesidad de «aniquilamiento» del «enemigo subversivo» (Levín, 2013:28)

El anteúltimo capítulo titulado «El humor y la guerra» se centra exclusivamente en el análisis de la Guerra de Malvinas. Aquí se reconstruye el entramado de la crónica bélica ofrecida a los lectores de Clarín a través de los espacios de humor. A partir de las imágenes en este período ya se puede ir visualizando el balance de los militares en el marco de la derrota bélica, así también los primeros trabajos colectivos de construcción social sobre el pasado a los que no fueron ajenos los humoristas del diario.

Por último, en el sexto capítulo llamado «El humor en tránsito» se explora la construcción de nuevos sentidos sobre lo que comienza a ser el pasado, así como de una nueva identidad política democrática y antimilitar (Levín, 2013:29) El nombre de este capítulo justamente se debe a que se explora una etapa de transición. Con la guerra de Malvinas se terminó de desvanecer el poder de los militares y trajo como consecuencia el advimiento de la democracia. Al fi

propone al lector una serie de vińetas que son las utilizadas en el cuerpo del análisis del libro de modo secuencial y cronológico. 
Un aporte significativo que nos ofrece el libro de Florencia Levín se relaciona con el uso del humor gráfi

Esto es de suma importancia dado que nos permite tomar a las viñetas y cartoons no como meras ilustraciones y ejemplos de procesos históricos sino por el contrario, como fuentes para el abordaje y la enseńanza de la Historia Reciente. De esta manera podemos pensar a las imágenes como elementos fundamentales para rastrear las representaciones que circulaban y eran consumidas en el espacio público.

Gracias al arduo trabajo desarrollado en esta investigación, el humor se convierte en una herramienta importante que habilita no sólo nuevos interrogantes sino que nos permite seguir pensando sobre cómo fue posible el horror. Sin lugar a dudas es un libro que nos invita a la reflexión y análisis de la Historia Reciente Argentina. 